\title{
Pengaturan Corporate Social Responsibility Berdasarkan Guiding Principles on Business and Human Rights
}

\author{
Gusti Fadhil Fithrian Luthfan \\ Pascasarjana Fakultas Hukum Universitas Islam Indonesia \\ Jln. Cik Di Tiro No. 1 Yogyakarta \\ gustifadhil@gmail.com
}

\begin{abstract}
This study aims to analyze the role of UNGP in constructing CSR legal policies in Indonesia and the implementation of CSR for companies, in order to create effective, targeted and beneficial CSR for the country, companies and society. This research is a normative study using a statutory approach, historical approach, conceptual approach and comparative approach. The results showed that according to UNGP, there is a principle of the company's obligation to respect human rights, so the company has a tool for accountability with human rights due diligence. This human rights due diligence serves to identify, prevent, mitigate and account for the impact of human rights violations that arise. In Indonesia, these UNGP principles need to be adopted in legislation such as that of France in order to create an effective, targeted and useful CSR.
\end{abstract}

Keywords: Corporate social responsibility; uman rights; UN guiding principles on business and human rights

\begin{abstract}
Abstrak
Penelitian ini bertujuan untuk menganalisis peran UNGP dalam mengkonstruksi kebijakan hukum CSR di Indonesia dan pelaksanaan CSR bagi perusahaan, agar dapat terciptanya CSR yang efektif, tepat sasaran dan bermanfaat bagi negara, perusahaan, dan masyarakat. Penelitian ini merupakan penelitian normatif dengan menggunakan pendekatan perundang-undangan, pendekatan historis, pendekatan konseptual dan pendekatan komparatif. Hasil penelitian menyimpulkan bahwa menurut UNGP, terdapat prinsip kewajiban perusahaan untuk menghormati hak asasi manusia, maka perusahaan mempunyai alat pertanggungjawaban dengan uji tuntas HAM (human rights due diligence). Human rights due diligence ini berfungsi untuk mengidentifikasi, mencegah, mitigasi, dan mempertanggungjawabkan dampak pelanggaran HAM yang timbul. Di Indonesia, prinsip-prinsip UNGP ini perlu diadopsi di dalam peraturan perundang-undangan seperti yang dilakukan Perancis agar tercipta CSR yang efektif, tepat sasaran, dan bermanfaat.
\end{abstract}

Kata-kata Kunci: Hak asasi manusia; corporate social responsibity; UN guiding principles on business and human rights 


\section{Pendahuluan}

Gloalisasi merupakan titik balik dari perkembangan umat manusia yang telah menciptakan suatu tatanan masyarakat yang borderless, yaitu suatu tatanan masyarakat yang saling memiliki hubungan dan kerapatan interaksi antar satu sama lain. Era yang dipicu akibat perkembangan industri dan teknologi ini tentunya berdampak terhadap iklim perekonomian suatu negara, tak terkecuali Indonesia. Perkembangan yang timbul dari proses globalisasi memunculkan tantangan yang memerlukan solusi tersendiri, termasuk yang berkaitan dengan hukum dalam bidang bisnis. Globalisasi juga turut memunculkan persaingan yang semakin tajam di antara pelaku usaha baik lokal maupun internasional. ${ }^{1}$

Salah satu bentuk imbas dari globalisasi adalah terbukanya keran pasar bebas dalam skala global seperti investasi secara luas yang banyak dilakukan oleh TNCs (Trans National Corporations) ke berbagai negara untuk memperluas jangkauan bisnis dan agar mendapatkan profit sebesar-besarnya dari kegiatan tersebut. Keuntungan tersebut dapat diperoleh dari berbagai faktor yang ada seperti upah buruh murah, dekat dengan sumber bahan mentah, prospek pasar baru, dan lain sebagainya. Hal ini kemudian semakin dikuatkan dengan kemunculan perjanjianperjanjian antar negara yang berorientasi pada kemudahan dalam berinvestasi. ${ }^{2}$

Kekuatan modal yang begitu besar dan teknologi yang mutakhir, kehadiran TNCs maupun perusahaan lokal bermodal besar diharapkan dapat mengelola sumber daya alam yang dimiliki oleh negara dengan baik serta berimbas pada pemerataan pembangunan, meningkatkan ekspor, pemasukan pajak, membuka lapangan pekerjaan baru dan pengadaan alih teknologi bagi masyarakat. Namun keberadaan perusahaan di suatu wilayah memiliki dampak positif dan negatif. Ia merupakan entitas yang memiliki pengaruh paling signifikan dalam pertumbuhan ekonomi masyarakat, namun sering kali menimbulkan berbagai permasalahan serius bagi masyarakat. ${ }^{3}$

\footnotetext{
1 Joko Purnomo. et. al., 2017, Globalisasi dan Politik Pembangunan Internasional, UB Press, Malang, hlm. xxi.

2 Pieter Kuin, 1987, Perusabaan Trans Nasional, Yayasan Obor Indonesia, Jakarta, hlm. 6.

3 Sefriani, "Tanggung Jawab Perusahaan Transnasional terhadap Pelanggaran HAM dalam Perspektif Hukum Internasional”, Jurnal UNISLA, Vol 30, 2007, hlm. 291.
} 
Fakta beberapa tahun belakangan menunjukan bahwa perusahaan yang bergerak dalam bidang sumber daya alam atau yang berkaitan dengannya justru melakukan banyak pelanggaran HAM, seperti merusak lingkungan, melakukan pembakaran hutan untuk pembukaan lahan pertambangan dan pembuangan limbah ke sungai. ${ }^{4}$ Ironisnya dalam beberapa kasus bahkan perusahaan dapat menjadi ancaman bagi masyarakat sekitar tempat perusahaan tersebut menjalankan bisnis. ${ }^{5}$ Belum lagi ditambah dengan kerjasama terselubung antara pemerintah dengan perusahaan. ${ }^{6}$ Sehingga dapat menimbulkan anggapan bahwa keberadaan perusahaan di tengah-tengah masyarakat yang semestinya memberikan kemakmuran justru mendatangkan malapetaka bagi masyarakat sekitar dan tentu saja tindakan ini merupakan pelanggaran terhadap hak asasi manusia seperti hak untuk hidup, hak atas lingkungan yang sehat, dan hak atas rasa aman yang semestinya dapat dijamin oleh negara dan dihormati oleh semua pihak.

Kemampuan ekonomi yang dimiliki oleh suatu perusahaan transnasional yang melebihi kemampuan sebuah negara dapat mengintervensi kekuatan politik yang ada di negara tersebut merupakan fakta yang menimbulkan persoalan lain. Hal ini menjadi kombinasi yang sempurna dalam terciptanya pelanggaranpelanggaran hak asasi manusia yang sistematis dan masif. Menurut data laporan yang dikeluarkan oleh Komnas HAM, perusahaan di Indonesia secara umum menduduki tempat kedua sebagai pihak yang diadukan untuk indikasi pelanggaran hak asasi manusia. ${ }^{7}$

\footnotetext{
4 "Kepala Polri Jenderal Badrodin Haiti mengatakan bahwa pihaknya telah melakukan pemeriksaan pada ratusan orang dan sepuluh perusahaan yang disangka melakukan pembakaran hutan dan lahan di wilayah Sumatera dan Kalimantan.Saat ini, ada 127 orang yang telah ditetapkan menjadi tersangka." Lihat: https:/ / nasional.kompas.com/ read/2015/09/16/00320091/Sebanyak.127.Orang.dan.10.Perusahaan.Jadi.Tersangka.Kebak. aran.Hutan diakses pada 20 Agustus 2016

5 "Samsul alias Kancil, seorang petani di Desa Selok Awar-awar, Lumajang, tewas dibunuh karena aksinya menolak kegiatan penambangan pasir di wilayah Pantai Watu Pecak. Dia dianiaya kemudian dibunuh di depan Balai Desa karena, pada Sabtu (26/9) September 2015" Lihat: https://www.merdeka.com/peristiwa/walhi sebutpembunuban-petani-di-lumajang-karena-perusahaan-bermain.btml diakses 20 Agustus 2016

6 "Contoh kebijakan ekonomi pemerintah yang lebih menguntungkan pengusaha dan merugikan rakyat banyak bisa dilihat dari hasil penelitian Donny Tjahja Rimba dalam bentuk disertasi berjudul "Hubungan Negara dan Pengusaha di Era Reformasi. Studi Kasus: Bisnis Grup Bakrie (2004-2012)”. Dia mengatakan, kelompok Bisnis Bakrie dibuktikan telah mempengaruhi kebijakan negara setidaknya dalam dua kasus.Pertama, persoalan divestasi saham Newmont. Kasus kedua, bencana lumpur Lapindo. Lihat: https://m.kontan.co.id/news_analisis/kongkalikeongpenguasa-dan-pengusaha, diakses 5 Juli 2018

${ }^{7}$ Komisi Nasional Hak Asasi Manusia, 2016, Laporan Data Pengaduan Tabun 2015 Sub Bagian Penerimaan dan Pemilahan Pengaduan, Komnas HAM, Jakarta, hlm. 7.
} 
Tabel 1.8

Jumlah aduan terhadap pihak yang terindikasi melakukan pelanggaran HAM

\begin{tabular}{clccc}
\hline No & \multicolumn{1}{c}{ Pihak Yang Diadukan } & $\mathbf{2 0 1 4}$ & $\mathbf{2 0 1 5}$ & $\mathbf{2 0 1 6}$ \\
\hline 1 & Kepolisian & 2.483 & 2734 & 2.290 \\
2 & Perusahaan & 1.127 & 1231 & 1.030 \\
3 & Pemerintah Daerah & 771 & 1011 & 931 \\
4 & Lembaga Peradilan & 641 & 640 & 436 \\
5 & Pemerintah Pusat (Kementerian) & 499 & 548 & 619 \\
\hline
\end{tabular}

Permasalahan ini kemudian dihadapi dengan kemunculan instrumen hak asasi manusia yang baru pada tahun 2011, yaitu Guiding Principles On Business And Human Rights (UNGP). Instrumen ini secara sederhana dapat dibagi dalam 3 kerangka pikir, yaitu kewajiban negara untuk melindungi hak asasi manusia (protect), kewajiban perusahaan untuk menghormati hak asasi manusia (respect), dan akses pemulihan (remedy). ${ }^{9}$ Prinsip ini menempatkan kedudukan perusahaan sebagai subjek hukum dalam rezim hukum hak asasi manusia internasional dengan meletakan tanggung jawab perusahaan pada bentuk tanggung jawab kewajiban perusahaan untuk menghormati hak asasi manusia (obligation to respect). Tidak mencakup tanggung jawab melindungi (obligation to protect) yang mana merupakan tugas negara untuk menjalankannya. ${ }^{10}$

Perusahaan, di sisi lain juga mempunyai kewajiban untuk menyeimbangkan antara profit yang didapat dengan hak-hak sosial dan lingkungan masyarakat yang mendapat dampak dari kegiatan perusahaan. Corporate Social Responsibility (CSR) merupakan program yang dijadikan sebagai tanggung jawab sosial perusahaan, yang kemudian diyakini sebagai suatu program yang dapat mendamaikan hubungan antara kegiatan bisnis dengan hak asasi manusia. Meskipun CSR telah diatur sebagai program wajib perusahaan,11 namun konsep CSR yang dilaksanakan di Indonesia belum berorientasi pada hak asasi manusia. Di Indonesia, banyak perusahaan masih

8 Komisi Nasional Hak Asasi Manusia, “Tindakan Aktif Bagian Dukungan Pelayanan Pengaduan KOMNAS HAM", Laporan Tabunan 2016, Bagian Dukungan Pelayanan Pengaduan Biro Dukungan Penegakan HAM, KOMNAS HAM, Jakarta, 2017, hlm. 25

${ }^{9}$ Guiding Principles On Business And Human Rights, 2011, United Nations Human Rights, hlm. 1

10 Ifdhal Kasim, 2014, "Menuju Bisnis yang Menghargai Hak. Asasi Manusia", Pengantar dalam Bagaimana Menjalankan Bisnis dengan Menghormati Hak Asasi Manusia, Global Compact Network Netherlands, Elsam, Jakarta, hlm. xiii.

${ }^{11}$ Lihat Pasal 74 UU NO. 40 Tahun 2007 tentang Perseroan Terbatas, Pasal 3 Peraturan Pemerintah Nomor 47 Tahun 2012 tentang Tanggung Jawab Sosial dan Lingkungan Perseroan Terbatas. 
enggan menyelenggarakan CSR karena dianggap hanya sebagai pengeluaran biaya (cost center) saja, dan tidak memberikan hasil secara keuangan dalam jangka pendek.12 CSR juga seringkali disalahgunakan oleh perusahaan dalam aktivitas social marketingnya dengan mewujudkan CSR sebagai bentuk marketing gimmick untuk melakukan corporate greenwash atau pengelabuan citra perusahaan belaka. ${ }^{13}$

Berdasarkan hal-hal di atas, terlihat bahwa pelaksanaan CSR oleh perusahaan selama ini masih berorientasi pada aspek keuntungan dari sisi perusahaan, belum sampai pada level orientasi terhadap isu hak-hak asasi manusia. Selain itu, pengaturan CSR yang ada di dalam peraturan perundang-undangan sebatas pada perusahaan-perusahaan yang bergerak di bidang sumber daya alam. ${ }^{14}$ Oleh karena itu, penelitian ini bermaksud untuk menganalisis bagaimana peran UNGP dalam mengkonstruksikan kembali kebijakan hukum CSR di Indonesia dan pelaksanaan CSR bagi perusahaan, agar dapat terciptanya CSR yang efektif, tepat sasaran dan bermanfaat bagi negara, perusahaan, dan masyarakat.

\section{Rumusan Masalah}

Permasalahan dalam penelitian ini adalah bagaimana peran UNGP dalam mengkonstruksi kebijakan hukum CSR di Indonesia dan pelaksanaan CSR bagi perusahaan, agar dapat terciptanya CSR yang efektif, tepat sasaran dan bermanfaat bagi negara, perusahaan, dan masyarakat?

\section{Tujuan Penelitian}

Tujuan penelitian ini adalah untuk menganalisis peran UNGP dalam mengkonstruksi kebijakan hukum CSR di Indonesia dan pelaksanaan CSR bagi perusahaan, agar dapat terciptanya CSR yang efektif, tepat sasaran dan bermanfaat bagi negara, perusahaan, dan masyarakat.

\footnotetext{
${ }^{12}$ Sukriyah Kustanti Moerad, "Impementasi dan Evaluasi Corporate Sosial Responsibility (CSR) di Perusahaan Pengeboran Minyak Petrocina Kabupaten Bojonegoro - Jawa Timur”, Jurnal Sosial Humaniora, Vol. 4 No. 1 Juni 2011, hlm. 53

13 Neni Yulianita, "Corporate Social Responsibility (CSR) sebagai Aktivitas Social Marketing Public Relations", Mediator, Vol. 9 No. 1 hlm. 127

${ }^{14}$ Lihat Pasal 74 UU No. 40 Tahun 2007 tentang Perseroan Terbatas, Pasal 3 PP No. 47 Tahun 2012 tentang Tanggung Jawab Sosial dan Lingkungan
} 


\section{Metode Penelitian}

Penelitian ini merupakan penelitian hukum normatif dengan menggunakan beberapa pendekatan. Beberapa pendekatan yang digunakan dalam penelitian ini adalah pendekatan perundang-undangan (statute approach), pendekatan historis, pendekatan konsep (conceptual approach), serta pendekatan perbandingan (comparative approach). Bahan hukum yang digunakan dalam penelitian ini yaitu bahan hukum primer, yaitu UU No. 40 Tahun 2007 tentang Perseroan Terbatas, UU No. 25 Tahun 2007 tentang Penanaman Modal, PP No. 47 Tahun 2012 tentang Tanggung Jawab Sosial dan Lingkungan Perseroan Terbatas, dan instrumen hukum internasional seperti UNGP. Untuk mendukung bahan hukum primer, tulisan ini menggunakan bahan hukum sekunder, yaitu buku, jurnal, artikel, kamus hukum dan literatur lain yang berkaitan dengan pokok bahasan. Bahanbahan hukum tersebut dikumpulkan melalui metode studi pustaka atau studi literatur yang kemudian hasil dari penelitian ini akan disajikan dalam bentuk deskriptif analitis.

\section{Hasil Penelitian dan Pembahasan}

Peran UN Guiding Principles on Business and Human Rights dalam Mengkonstruksi Kebijakan Hukum Corporate Social Responsibility di Indonesia

Terdapat paradigma lama dalam dunia HAM bahwa perusahaan sebagai aktor non-negara, bukanlah pemangku kewajiban untuk melindungi, menghormati, dan memenuhi hak asasi manusia. Oleh karenanya, perusahaan tidak dapat dimintai pertanggung jawaban hukum (legal responsibility) untuk menghormati hak asasi manusia. ${ }^{15}$ Anggapan ini kemudian tergantikan dengan kemunculan paradigma baru dalam dunia HAM bahwa perusahaan sebagai aktor non-negara dapat diminintai pertanggungjawaban untuk melakukan pemenuhan HAM. Hal ini dapat merujuk pada Committee on Economic, Social, and Cultural Rights (CESC) General Comments No. 12 Paragraph 20 yang menegaskan bahwa:16

15 Asep Mulyana, Paper Bisnis dan HAM: Menurunkan Prinsip Menjadi Praktik, Pusat Dokumentasi Elsam, Jakarta, 2016, hlm.2. Lihat: www.elsam.or.id

16 Sefriani dan Sri Wartini, Op, Cit., hlm. 19 
"While only States are parties to the Covenant and are thus ultimately accountable for compliance with it, all members of society - individuals, families, local communities, non-governmental organizations, civil society organizations, as well as the private business sector - have responsibilities in the realization of the right to adequate food. The State should provide an environment that facilitates implementation of these responsibilities." 17

"Selain negara sebagai pihak dalam kovenan yang diwajibkan untuk bertanggung jawab dan patuh terhadap terhadap isi kovenan namun setiap anggota masyarakat - individu, keluarga, komunitas lokal, organisasi nonpemerintah, organisasi masyarakat sipil, serta sektor bisnis swasta - turut memiliki tanggung jawab dalam merealisasikan hak atas pangan yang memadai dan negara harus menyediakan lingkungan yang memfasilitasi pelaksanaan tanggung jawab ini."

Selain General Comments penegasan aktor non-negara sebagai pemangku kewajiban untuk melindungi dan menghormati HAM juga terdapat dalam "Code of Conduct for Transnational Corporation" yang berbunyi: 18

"Transnational corporations should/shall respect human rights and fundamental freedoms in the countries in which they operate. In their social and industrial relations, transnational corporations should/shall not discriminate on the basis of race, colour, sex, religion, language, social, national and ethnic origin or political or other opinion. Transnational corporations should/shall conform to government policies designed to extend equality of opportunity and treatment."19

"Perusahaan transnasional harus menghormati hak asasi manusia dan kebebasan fundamental di negara-negara tempat mereka beroperasi. Dalam hubungan sosial dan industri, perusahaan transnasional harus/tidak boleh melakukan diskriminasi atas dasar ras, warna kulit, jenis kelamin, agama, bahasa, sosial, asal-usul nasional dan etnis atau pendapat politik atau lainnya. Perusahaan transnasional wajib mematuhi kebijakan pemerintah yang dirancang untuk memperluas kesempatan dan perlakuan yang sama."

Penempatan TNCs sebagai aktor non-negara, yang awalnya tidak bertanggung jawab menjadi bertanggung jawab atas pelanggaran HAM, merupakan bentuk pergeseran paradigma dalam diskursus hak asasi manusia. Pada mulanya, norma-norma HAM menempatkan individu sebagai pemegang hak

17 Committee on Economic, Social, and Cultural Rights (CESC) General Comments No. 12 The Right to Adequate Food (Art. 11) sumber:http://www.refworld.org/docid/4538838c11.html diakses pada 7 Juli 2018

${ }_{18}$ Rhona K.M. Smith et., al., 2008, Hukum Hak Asasi Manusia, Cetakan Pertama, Pusat Studi Hak Asasi Manusia Universitas Islam Indonesia, Yogyakarta, hlm. 55.

19 United Nation Code of Conduct on Transnational Corporation, sumber: http://investmentpolicyhub.unctad.org/Download/TreatyFile/2891 diakses: 7 Juli 2017 
(right holders) dan negara sebagai pemangku kewajiban (duties holder). Negara mempunyai kewajiban untuk menghormati, melindungi dan memenuhi hak asasi manusia. Hal ini disebabkan karena sejarah pelanggaran HAM yang pernah terjadi sebelumnya hanya dilakukan oleh negara terhadap hak sipil dan politik maupun hak ekonomi, sosial, dan budaya. Negara adalah satu-satunya pengemban kewajiban terhadap HAM. Adapun pihak selain negara adalah pemegang hak. Hal ini dapat dipahami karena dalam perspektif hukum internasional klasik, satusatunya subjek hukum internasional adalah negara. ${ }^{20}$

Perlindungan, penegakan, dan pemajuan hak asasi manusia juga terkait erat dengan kebijakan di bidang ekonomi, dan politik suatu negara. Bahkan, seringkali di negara-negara berkembang, kebijakan tersebut dibuat bersama atau atas dasar instruksi lembaga pendanaan internasional dan kepentingan investasi perusahaan transnasional. ${ }^{21}$ Sehingga, dalam konteks perkembangan industri dan globalisasi, pada akhirnya banyak negara yang memiliki ketergantungan terhadap perusahaan transnasional dalam rangka menjaga stabilitas ekonomi domestik. Perusahaanperusahaan ini memang memiliki pengaruh yang cukup kuat. Mereka menggalang dukungan dari berbagai pihak seperti militer, politik nasional dan internasional, legislatif, serta menguasai media dan pasar global. ${ }^{22}$

Besarnya kekuatan perusahaan multinasional bahkan dapat mengalahkan kekuatan negara. Kekayaan 200 perusahaan besar di dunia juah lebih besar dari kekayaan 182 negara. Nilai penjualan perusahaan tersebut mencapai US\$ 8.300.000.000.000, dan mengontrol 27,5\% GDP di dunia. Ini berarti nilai penjualan perusahaan-perusahaan tersebut mencapai lebih dari 18 kali pendapatan 1,2 miliar penduduk dunia. Perusahaan ini bergerak tidak mengenal batas negara dan memperkerjakan lebih dari 1,8 juta karyawan. ${ }^{23}$ Atas dasar ini kemudian muncul anggapan bahwa pelanggaran hak asasi manusia tidak sepenuhnya menjadi tanggung jawab negara saja, tetapi juga terdapat tanggung jawab kekuatan

\footnotetext{
${ }^{20}$ Sefriani, Op. Cit., hlm. 47

${ }^{21}$ Rhona K. M. Smith, Op. Cit., hlm. 55.

22 Jawahir Thontowi, Hukum dan Hubungan Internasional, UII Press, Yogyakarta, 2016, hlm. 75.

${ }^{23}$ Isa Wahyudi dan Busyra Azheri, Corporate Social Responsibility: Prinsip, Pengaturan dan Implementasi, Setara Press, Malang, hlm. 117-121
} 
ekonomi pilitik lain seperti lembaga pendanaan internasional dan perusahaan transnasional.

Besarnya pengaruh suatu entitas bisnis dalam kehidupan umat manusia mendorong komunitas internasional untuk mendesak komunitas bisnis agar mau untuk terlibat dalam penghormatan hak asasi manusia dan bertanggung jawab terhadap segala dampak yang ditimbulkan dari kegiatan bisnis. Di samping itu terdapat beberapa faktor yang menjadikan bisnis dan HAM naik ke permukaan, diantaranya: ${ }^{24}$

a. Meningkatnya kesadaran konsumen dan tuntutan publik atas transparansi pemerintah dan perusahaan;

b. Minat yang besar dari para pemangku kepentingan untuk mengadopsi isu dan topik terkait kepentingan bisnis dan HAM;

c. Sorotan tajam dunia terhadap perusahaan terkait kasus-kasus besar, misalnya Freeport di Indonesia, Shell di Nigeria.

Selama beberapa tahun, CSR telah menjadi salah satu kajian yang juga paling diperhatikan oleh komunitas internasional. Tanggung jawab sosial perusahaan diyakini sebagai suatu program yang dapat mendamaikan hubungan antara kegiatan bisnis dengan hak asasi manusia. Oleh karena itu, berbagai instrumen mulai dirumuskan untuk menjawab persoalan tersebut, seperti Deklarasi Tripartit Organisasi Perburuhan Internasional (ILO) tentang Prinsip-Prinsip Mengenai Perusahaan Transnasional dan Kebijakan Sosial, Pedoman untuk Perusahaan Transnasional yang dikeluarkan oleh Organisation for Economic Co-Operation and Development (OECD) pada 1976. Sub-komisi Perserikatann Bangsa-Bangsa (PBB) untuk promosi dan perlindungan hak asasi manusia juga membentuk kelompok kerja yang menguraikan prinsip-prinsip hak asasi manusia yang dapat mengikat bagi entitas bisnis dengan merumuskan UN Global Compact.25 Regulasi yang mencakup kode etik perusahaan tersebut diperkenalkan ke Parlemen Australia dan Kongres Amerika Serikat, dimana 85 persen perusahaan besar telah mengadopsi

\footnotetext{
${ }^{24}$ Asep Mulyana, “Mengintegrasikan HAM ke Dalam Kebijakan dan Praktik Perusahaan,” Jurnal HAM, Vol 8 Tahun 2012, hlm. 272.

25 Alexandra J. C. Gatto, "The European Union and Corporate Social Responsibility: Can the EU Contribute to the Accountability of Multinational Enterprises for Human Rights?”, Working Paper No. 32, Institute for International Law, K. U. Leuven Faculty of Law, September 2002, hlm. 5
} 
prinsip kesukarelaan (voluntary code of conduct) tanggung jawab sosial perusahaan. Inisitif ini dapat disambut sebagai bentuk tanggung jawab perusahaan terhadap hak asasi manusia dan masyarakat secara umum. ${ }^{26}$

Jimly Asshiddiqie dalam membicarakan perkembangan hak asasi manusia, mengusulkan suatu konsep generasi keempat hak asasi manusia, yaitu konsep hak asasi manusia yang dipahami dalam konteks hubungan yang bersifat horizontal. Hal ini berlainan dengan perkembangan hak asasi manusia berdasarkan tiga generasi yang memiliki karateristik hubungan kekuasaan yang bersifat vertikal. Setiap pelanggaran terhadap hak asasi manusia mulai dari generasi pertama sampai ketiga selalu melibatkan peran pemerintah yang biasa dikategorikan sebagai crime by government yang termasuk ke dalam pengertian political crime (kejahatan politik) sebagai lawan dari pengertian crime against government (kejahatan terhadap kekuasaan resmi). Karena itu, yang selalu dijadikan sasaran perjuangan hak asasi manusia adalah kekuasaan represif negara terhadap rakyatnya. ${ }^{27}$

Menurut Jimly, dalam perkembangan zaman sekarang dan di masa-masa mendatang, dimensi-dimensi hak asasi manusia itu akan berubah makin kompleks sifatnya. Persoalan hak asasi manusia tidak cukup hanya dipahami dalam konteks hubungan kekuasaan yang bersifat vertikal, tetapi mencakup pula hubunganhubungan kekuasaan yang bersifat horizontal, antar kelompok masyarakat, antara golongan rakyat atau masyarakat, dan bahkan antar satu kelompok masyarakat di suatu negara dengan kelompok masyarakat di negara lain. Inilah yang dimaksud olehnya sebagai perkembangan hak asasi manusia Generasi Keempat. ${ }^{28}$

Pengalaman gugurnya gugatan-gugatan HAM terhadap perusahaan transnasional mendorong adanya perluasan konsep pertanggungjawaban (liability) untuk pelanggaran HAM agar perusahaan multinasional dapat dimintai pertanggungjawabannya dengan dasar hukum perjanjian HAM internasional. Argumen pertama berlandaskan pada Deklarasi Universal Hak Asasi Manusia (DUHAM) yang menyebutkan bahwa "every individual and every 'organ of society

\footnotetext{
26 Ibid., hlm. 6

${ }^{27}$ Jimly Asshiddiqie, Hukum Tata Negara dan Pilar-Pilar Demokrasi, Konstitusi Press, Jakarta, 2005, hlm. 221-225

${ }^{28}$ Ibid
} 
society' to play their part in securing the observance of human rights." Perusahaan yang dikategorikan sebagai "organ of society society" memiliki tanggung jawab dalam rangka mempromosikan dan menghormati hak asasi manusia. ${ }^{29}$

Gagasan HAM dan bisnis mengalami tarik ulur yang sudah berlangsung lama selama kurang lebih hampir tiga dasawarsa. Dari diskursus ini banyak melahirkan inisiatif dari berbagai pihak yang mendorong perusahaan untuk lebih memperhatikan dan menghormati HAM, sebut saja OECD Guidelines for Multinational Corporations and Principles of Corporate Governance dan UN Global Compact. Pada 1998, sebuah badan di bawah komisi HAM PBB juga merumuskan suatu rancangan norma mengenai tanggung jawab perusahaan terkait HAM dan diterbitkan pada 2003 dengan tajuk "Norms on the Responsibilitis of Transnational Corporation and Other Business Enterprises with Regard to Human Rights" atau yang dikenal dengan The Draft Norms. Norma tersebut membebankan tanggung jawab yang mengikat perusahaan secara langsung di bawah rezim hukum HAM internasional, meskipun negara tetap sebagai pemangku kewajiban utama. Kewajiban perusahaan mengikat di mana perusahaan itu memiliki pengaruh. Namun demikian, norma tersebut ditentang kelompok bisnis, tetapi didukung kelompok pembela HAM. Komisi HAM lalu batal mengadopsi dokumen tersebut, tetapi meminta Sekjen PBB mengangkat Perwakilan Khusus (Special Representative) PBB untuk Bisnis dan HAM, John Ruggie, untuk mengidentifikasi peran dan tanggung jawab negara, perusahaan, dan aktor lain dalam bisnis dan HAM. ${ }^{30}$

Berangkat dari kegagalan Draft Norms, Ruggie berusaha untuk mengidentifikasi dan mengklarifikasi standar dan praktik dari kegiatan bisnis dan hak asasi manusia serta melakukan pemetaan terhadap pola pelanggaran hak asasi manusia yang dilakukan oleh perusahaan, perkembangan hukum hak asasi manusia internasional, dan model kebijakan negara terkait kegiatan bisnis. ${ }^{31}$ Tahun 2008, Ruggie berhasil mengembangkan kerangka kerja (framework) untuk untuk

${ }^{29}$ Asep Mulyana, Op. Cit., hlm. 275.

${ }^{30}$ Ibid

31 John Ruggie, Report of the Special Representative of the Secretary-General on The Issue Of Human Rights And Transnational Corporations And Other Business Enterprises, UN Document A/HRC/17/31, 2011 
Bisnis dan HAM. Kerangka ini terdiri dari 3 pilar yang masing-masing menunjukan peranan dari setiap stakeholder yang terkait yaitu kewajiban negara untuk melindungi hak asasi manusia (protect), tanggung jawab perusahaan untuk menghormati hak asasi manusia (respect), dan akses pemulihan (remedy). Kemudian pada Juni 2011, Dewan HAM PBB mengesahkan kerangka tersebut menjadi Prinsip-Panduan Bisnis dan HAM atau yang dikenal dengan UN Guiding Principles on Bussines and Human Rights (UNGPs). ${ }^{32}$

Prinsip-prinsip panduan ini disusun berdasarkan pengakuan atas hal-hal berikut: ${ }^{33}$

a. Kewajiban Negara untuk melindungi, menghormati, dan memenuhi HAM dan kebebasan dasar;

b. Peran perusahaan bisnis sebagai organ khusus dari masyarakat yang melakukan fungsi-fungsi khusus, sehingga harus mengikuti peraturan yang berlaku dan menghormati hak asasi manusia;

c. Kebutuhan akan hak dan kewajiban yang sesuai dengan pemulihan yang layak dan efektif ketika dilanggar.

Prinsip-prinsip panduan ini berlaku bagi semua negara dan semua bisnis, baik transnasional maupun lainnya, terlepas dari besarnya, sektor, lokasi kepemilikan dan struktur dari perusahaan tersebut. Selanjutnya panduan ini harus dipahami sebagai satu kesatuan yang utuh dan harus dibaca secara bersama-sama dan tidak terpisah, dalam hal tujuan memajukan standar dan praktik yang berkaitan dengan bisnis dan HAM untuk mencapai hasil nyata bagi komunitas dan individu yang terkena dampaknya, dan maka dari itu juga memberikan kontribusi kepada sebuah globalisasi sosial yang berkelanjutan. ${ }^{34}$

Keberadaan prinsip panduan ini bukan dimaksudkan untuk menciptakan kewajiban hukum internasional yang baru, atau untuk membatasi atau mengesampingkan kewajiban hukum apapun yang mungkin dimiliki oleh suatu negara atau menjadi subyek hukum internasional terkait dengan hak asasi manusia. Prinsip-prinsip panduan tersebut harus diterapkan secara non-

${ }^{32}$ Tim Penyusun, Buku Saku: Prinsip-Prinsip Panduan untuk Bisnis dan Hak. Asasi Manusia: Kerangka Perserikatan Bangsa-Bangsa Perlindungan, Penghormatan, dan Pemulihan, Konsil LSM Indonesia dan ICCO, Jakarta, 2018, hlm. 1-2

33 Guiding Principles on Business and Human Rights: Implementig the United Nations Protect, Respect, Remedy Framework, New York: UNHR, 2011, hlm. 1

34 Ibid 
diskriminatif, dengan perhatian khusus kepada hak-hak dan kebutuhan dan tantangan yang dihadapi oleh individu-individu dari kelompok atau komunitas yang berpotensi menjadi rentan atau termarjinalkan, dan dengan perhatian terhadap resiko berbeda yang mungkin dihadapi oleh perempuan dan laki-laki. ${ }^{35}$

Berdasarkan berbagai pemaparan sebelumnya mengenai tanggung jawab sosial dan lingkungan perusahaan, terdapat beberapa hal yang dapat dilihat terkait hubungannya dengan HAM dan bisnis secara umum maupun dengan UN Guiding Principles on Buisness and Human Rights secara khusus sebagai instrumen yang memberikan panduan untuk melakukan kegiatan bisnis sebagaimana dikehendaki oleh rezim hukum HAM internasional.

Banyak negara yang menyambut baik kelahiran UNGPs. Pada 2009 European Union Presidency dalam membahas UN protect, respect, remedy framework mengatakan bahwa kerangka ini dapat memberikan kunci dalam praktik pengembangan CSR global. Kemudian Menteri luar negeri Norwegia juga berpendapat bahwa kerangka ini sejalan dengan konsep CSR. ${ }^{36}$ UNGPs hadir atas dasar keresahan yang diakibatkan oleh pengaruh dan cengkraman perusahaan transnasional yang keberadaannya meningkat secara drastis dalam beberapa dekade terakhir. Pada saat yang sama, kemampuan beberapa negara untuk mengatur dan mencegah dampak-dampak merugikan dari kegiatan bisnis belum mencapai kecepatan yang sama. Akibatnya, banyak kelompok masyarakat yang mengalami kerugian karena tidak adanya mekanisme perlindungan atau lemahnya penegakan hukum.

Pemerintah Indonesia dalam ranah CSR atau tanggung jawab sosial dan lingkungan (TJSL) mengatur tentang kewajiban bagi setiap pelaku usaha dalam bidang sumber daya alam atau yang berkaitan dengannya untuk bertanggung jawab atas kondisi lingkungan dan masyarakat tempat dimana perusahaan tersebut menjalankan bisnisnya. Peraturan mengenai ini secara umum tertuang dalam Pasal 74 Undang-Undang Nomor 40 Tahun 2007 tentang Perseroan

35 Ibid

36 Special Representative of the United Nations, , Applications of the U.N. "Protect, Respect and Remedy" Framework, Secretary-General for business \& buman rights, Juni 2011, sumber: https://www.businesshumanrights.org/sites/default/files/media/documents/applications-of-framework-jun-2011.pdf diakses 4 November 2018 
Terbatas $^{37}$ (UU PT) dan Peraturan Pemerintah Nomor 47 Tahun 2012 tentang Tanggung Jawab Sosial dan Lingkungan Perseroan Terbatas (selanjutnya disebut PP TJSL).

TJSL sendiri menurut UU PT Pasal 1 ayat (3) merupakan "komitmen Perseroan untuk berperan serta dalam pembangunan ekonomi berkelanjutan guna meningkatkan kualitas kehidupan dan lingkungan yang bermanfaat, baik bagi Perseroan sendiri, komunitas setempat, maupun masyarakat pada umumnya." Dalam UU PT Pasal 74 dan PP TJSL menyatakan dengan tegas bahwa "setiap Perusahaan yang menjalankan kegiatan usaha di bidang sumber daya alam atau yang berkaitan dengannya wajib untuk melaksanakan kegiatan tanggung jawab sosial dan lingkungan, dan akan dikenakan sanksi apabila tidak dilaksanakan." Namun ketentuan mengenai bentuk sanksi yang dikenakan kepada perusahaan yang tidak melaksanakan TJSL tidak diatur dalam kedua peraturan ini dan merujuk pada undang-undang terkait. ${ }^{38}$

Aturan yang terkait mengenai tanggung jawab sosial dan lingkungan perusahaan dapat ditemukan dalam UU No. 25 Tahun 2007 tentang Penanaman Modal (selanjutnya disebut UU Penanaman Modal) yaitu pada Pasal 15, 16, 17 dan 34. Namun, dalam undang-undang ini terminologi yang digunakan adalah tanggung jawab sosial perusahaan, bukan tanggung jawab sosial dan lingkungan sebagaimana istilah yang digunakan dalam UU PT. Dalam UU ini, tanggung jawab sosial memiliki arti sebagai "tanggung jawab yang melekat pada setiap perusahaan penanaman modal untuk tetap menciptakan hubungan yang serasi, seimbang, dan sesuai dengan lingkungan, nilai, noma, dan budaya masyarakat setempat."39 UU ini mewajibkan perusahaan penanam modal untuk melaksanakan kegiatan tanggung jawab sosial, serta turut mengamanatkan pelaku usaha untuk menghormati tradisi budaya masyarakat sekitar dan menjaga kelestarian lingkungan. Di samping itu, juga

${ }^{37}$ Pasal 74 UU No 40 Tahun 2007 tentang Perseroan Terbatas berisikan tentang kewajiban perseroan yang menjalankan kegiatan usaha di bidang dan/atau berkaitan dengan sumber daya alam untuk melaksanakan tanggung jawab social dan lingkungan.

${ }^{38}$ Di dalam Pasal 74 ayat (3) UU PT dijelaskan bahwa "Perseroan yang tidak melaksanakan kewajiban sebagaimana dimaksud pada ayat (1) dikenai sanksi sesuai dengan ketentuan peraturan perundang-undangan". Kemudian dijelaskan lebih lanjut di dalam Penjelasan Pasal 74 ayat (3) UU PT yang berbunyi "Yang dimaksud dengan "dikenai sanksi sesuai dengan ketentuan peraturan perundang-undangan" adalah dikenai segala bentuk sanksi yang diatur dalam peraturan perundang-undangan terkait." Di dalam PP TJSL, peraturan mengenai sanksi juga tidak diatur lebih lanjut. Bahkan penormaan mengenai sanksi perusahaan yang tidak menjalankan CSR sama dengan pengaturan di dalam UU PT.

${ }^{39}$ Lihat Penjelasan Pasal 15 huruf b UU No. 25 Tahun 2007 tentang Penanaman Modal. 
terdapat aturan mengenai sanksi-sanksi berupa sanksi administratif sampai pada pencabutan kegiatan usaha. ${ }^{40}$

Tanggung jawab sosial dan lingkungan perusahaan, dalam konteks HAM, erat kaitannya dengan hak ekonomi, sosial, dan budaya (ekosob). ${ }^{41}$ TJSL dapat menjadi salah satu bentuk sarana pemenuhan hak-hak tersebut. Ditentukannya penormaan TJSL sebagai kewajiban (legal mandatory) juga tidak menjamin terciptanya ketertiban dalam pengaturan dan pelaksanaan TJSL di Indonesia. Ketidakjelasan peraturan, tumpang tindih peraturan, serta banyaknya pengaduan dan kasus pelanggaran HAM yang dilakukan oleh perusahaan merupakan bukti bahwa perlunya dilakukan pembenahan dalam aspek ini.

UNGPs menyebutkan bahwa adalah kewajiban pokok negara untuk menghormati hak asasi manusia. Namun sebagaimana telah dibahas sebelumnya, bahwa keberadaan prinsip panduan ini bukan dimaksudkan untuk menciptakan kewajiban hukum internasional yang baru, atau untuk membatasi atau mengesampingkan kewajiban hukum apapun yang mungkin dimiliki oleh suatu negara. Tetapi seperti yang dikatakan oleh UN High Commissioner for Human Rights, Zeid Ra'ad Al Hussein, yang menyebut UNGPs sebagai "the global authoritative standard, providing a blueprint for the steps all states and businesses should take to uphold human rights" atau standar otoritas global, yang menyediakan cetak biru sebagai langkah bagi setiap negara dan entitas bisnis untuk menegakan hak asasi manusia. Oleh karena itu, negara harus mengatur secara memadai terkait dampak dari kegiatan bisnis terhadap hak asasi manusia. ${ }^{42}$

${ }^{40}$ Lihat Pasal 34 UU No. 25 Tahun 2007 tentang Penanaman Modal. Ayat (1) "Badan usaha atau usaha perseorangan sebagaimana dimaksud dalam Pasal 5 yang tidak memenuhi kewajiban sebagaimana ditentukan dalam Pasal 15 dapat dikenai sanksi administratif berupa:

a. peringatan tertulis;

b. pembatasan kegiatan usaha;

c. pembekuan kegiatan usaha dan/atau fasilitas penanaman modal; atau

d. pencabutan kegiatan usaha dan/atau fasilitas penanaman modal.

Ayat (3) "Selain dikenai sanksi administratif, badan usaha atau usaha perseorangan dapat dikenai sanksi lainnya sesuai dengan ketentuan peraturan perundang-undangan."

${ }^{41}$ Sefriani dan Sri Wartini, "Corporate Social Responsibility dan Tanggung Jawab Negara Terhadap Hak Ekonomi, Sosial, dan Budaya di Indonesia”, Jurnal Yustisia, Edisi 92, 2015, hlm. 269.

42 Zeid Al Hussein, Ethical Pursuit of Porsperity, sumber: https://www.lawgazette.co.uk/analysis/ comment-and-opinion/ethical-pursuit-ofprosperity/5047796.fullarticle diakses 3 November 2018 
Uni Eropa adalah yang pertama kali mengambil sikap terkait hal ini. Bahkan Uni Eropa merubah definisi CSR yang sudah lama mereka rumuskan dari yang sebelumnya sebagai sebuah konsep di mana perusahaan mengintegrasikan kepedulian sosial dan lingkungan dalam operasi bisnis mereka dalam interaksinya dengan para pemangku kepentingan mereka secara sukarela, menjadi tanggung jawab perusahaan terhadap dampaknya kepada masyarakat (the responsibility of enterprises for their impacts to society). ${ }^{43}$ Uni Eropa juga mengatur bahwa pemerintah negara-negara yang berada di wilayahnya untuk mengembangkan National Action Plans atau Rencana Aksi Nasional dalam rangka mengimplementasikan ketiga prinsip yang termuat dalam UNGPs. Pengembangan tersebut dilakukan berdasarkan koordinasi, transparasi, dan fakta-fakta di lapangan serta menggunakan pendekatan campuran, yaitu dengan mengeluarkan aspek kebijakan yang bersifat voluntary dan mandatory. Diharapkan rencana ini dapat menunjukan kekosongan hukum dan kebijakan yang ada terkait dengan sector bisnis dan HAM. 44

Pengadopsian UNGPs ke dalam hukum nasional hanyalah salah satu langkah alternatif. Masing-masing negara dapat mengambil langkah berbeda sesuai dengan karakteristik sistem hukumnya. Namun hingga hari ini baru beberapa negara saja yang berhasil menurunkan prinsip ini menjadi praktik. Banyak perdebatan yang terjadi di tingkat nasional dan kurangnya kemauan (political will) yang menghambat tujuan implementasi UNGPs.

Salah satu upaya dalam mengimplementasikan UNGPs adalah menyusun sebuah Rencana Aksi Nasional (RAN). RAN ini disusun bersama-sama oleh seluruh pemangku kepentingan, di antaranya Pemerintah, Korporasi dan LSM/CSOs, termasuk National Human Rights Institution (NHRI). UNGP adalah instrumen yang membutuhkan keterlibatan seluruh pemangku kepentingan dalam

${ }^{43}$ European Comission, A renewed EU strategy 2011-14 for Corporate Social Responsibility, 2011, sumber: https://eur-lex.europa.eu/legalcontent/EN/TXT/PDF/?uri=CELEX:52011DC0681\&from=EN, diakses 5 November 2018

44 "5 Years of UNGPs: 5 Business and Human Rights Issues to Focus On" sumber: http://corporatejustice.org/news/135-5-years-of-ungps-5-business-human-rights-issues-to-focus-on diakses: 3 November 2018 
implementasinya, karena itu kekuatan UNGP bergantung pada proses dialog, pemahaman, dan kemauan untuk terus belajar dan memperbaiki kesalahan. 45

RAN itu sendiri merupakan dokumen kebijakan dimana negara mengartikulasikan prioritas dan tindakan yang akan dilakukan untuk mendukung pelaksanaan kewajiban dan komitmen internasional, regional, atau nasional yang berkaitan dengan area atau topik tertentu. ${ }^{46}$ RAN tidak memiliki sifat hukum yang mengikat. Ia hanyalah alat untuk mempromosikan upaya pencarian titik temu terkait praktik negara terhadap tujuan atau standar tertentu, tentang apakah diperlukannya kewajiban hukum, bagaimana bentuk peraturan dan apa saja kekurangannya, dan apa solusi terhadap problem yang bersifat kompleks. ${ }^{47}$

Proyek pembentukan RAN telah menjadi agenda tersendiri bagi UN Working Group on Business and Human Rights sebagai lembaga yang ditugaskan untuk menindaklanjuti UNGPs yang telah dirumuskan. Terdapat beberapa poin yang harus dilakukan dan dipertimbangkan untuk dimasukan ke dalam RAN, sebagaimana yang dirangkum oleh Bauer sekurang-kurangnya adalah berikut:48

1) Menyusun regulasi dan penerapan aturan yang menjadikan uji tuntas HAM sebagai syarat bagi keikutsertaan korporasi dalam tender pengadaan barang pemerintah, mendapatkan kredit ekspor, dan pencatatan (listing) sahamnya di bursa efek. Dimasukkannya kewajiban hak asasi manusia investor dalam perjanjian investasi bilateral dan dalam klausul penyelesaian sengketa investor-negara dari perjanjian tersebut;

2) Adopsi kewajiban HAM terhadap investor pada Bilateral Investment Treaties (BITs) dan perjanjian multilateral lainnya yang memfasilitasi perdagangan dan masuknya investasi asing;

3) Mengeluarkan undang-undang yang membuat uji tuntas hak asasi manusia perusahaan (sebagaimana ditentukan oleh pilar tanggung jawab perusahaan) sebagai prasyarat untuk kontrak pengadaan pemerintah, lisensi kredit ekspor, dan pencatatan bursa saham;

${ }^{45}$ International Corporate Accountability Roundtable (ICAR), National Action Plans on Business and Human Rights: A Toolkit for the Development, Implementation, and Review of State Commitments to Business and Human Rights Frameworks, Juni 2014, hlm. v

46 Ibid., hlm. 8.

47 Methven O'brien, C., Mehra, A., Blackwell, S., \& Poulsen-Hansen, C., "National Action Plans: Current Status and Future Prospects for a New Business and Human Rights Governance Tool”, Business and Human Rights Journal, 1(1), (2016), hlm. 117-126.

${ }^{48}$ Joanne Bauer, "Where Do National Action Plans on Business \& Human Rights Belong in the Corporate Sustainability Movement?," diakses melalui http://www.csrwire.com/blog/posts/1262-where-do-nationalaction-plans-on-business-human-rights-belong-in-the-corporate-sustainability-movement diakses 4 Mei 2018 
4) Mengkomunikasikan secara dini harapan negara terhadap korporasi asing misalnya, dengan mendorong staf diplomatik pada kedutaan besar dan perwakilan Indonesia di luar negeri untuk mengangkat masalah ini dengan pimpinan-pimpinan korporasi di negara asal mereka;

5) Memastikan dan mengawasi bahwa RAN yang disusun telah mencakup seluruh tugas instansi pemerintah terkait, serta pendapat buruh, LSM dan masyarakat terdampak telah didengar dan dipertimbangkan;

6) Memiliki target capaian dan kriteria capaian yang jelas, serta memiliki kerangka waktu bagi setiap tahapan capaian;

7) Memberikan perhatian khusus bagi daerah konflik dan kelompok rentan, termasuk perempuan, anak-anak, dan masyarakat adat;

8) Mendorong lembaga-lembaga pembuat kebijakan dan penyusun peraturan untuk mewajibkan penyusunan uji tuntas HAM oleh korporasi.

Penn State University Law School Professor Larry Catá Backer mengungkapkan kekhawatiran, bahwa dengan pengembangan proyek RAN yang seperti di atas akan "merusak" UNGPs karena seolah-olah membentuk hirarki di antara ketiga pilar tersebut. Menanggapi ini, Bauer justru beranggapan bahwa memang itulah yang menjadi tujuan dibentuknya RAN. Ia menambahkan "mandatory the second pillar is precisely what the project ought to be all about: closing the governance gaps" atau mewajibkan pilar kedua adalah inti dari proyek ini, yaitu untuk menutup kesenjangan tata kelola pemerintahan yang memungkinkan perusahaan untuk melakukan pelanggaran hak asasi manusia dan sebagai bentuk penyediaan aturan yang jelas terkait bisnis dan hak asasi manusia. ${ }^{49}$

Menengok negara lain, salah satunya Perancis, sebagai satu negara yang mengawali dalam menjadikan prinsip UNGPs ke dalam peraturan perundangundangan nasional. Pada tahun 2017, setelah melalui perjalanan yang cukup panjang disertai tekanan dari kelompok bisnis, French Constitutional Council akhirnya mengesahkan French Duty of Care Law. Aturan ini mewajibkan setiap perusahaan untuk melakukan uji tuntas hak asasi manusia (human rights due diligence) serta bertanggung jawab terhadap dampak pelanggaran HAM akibat 
kegiatan bisnis. ${ }^{50}$ Undang-undang ini berlaku tidak hanya bagi perusahaan yang ada di Perancis namun juga bagi perusahaan Perancis yang berada di luar negara. ${ }^{51}$

UU ini mengatur setiap perusahaan untuk harus menentukan, menerbitkan, dan mengimplementasikan apa yang disebut sebagai The Vigilance Plan atau Rencana Kewaspadaan. Rencana ini harus mencakup tindakan yang tepat untuk mengidentifikasi dan mencegah resiko pelanggaran yang serius terhadap hak asasi manusia dan kebebasan dasar, cedera serius, resiko kesehatan, serta kerusakan lingkungan yang ditimbulkan dari kegiatan perusahaan secara langsung maupun tidak langsung. Rencana Kewaspadaan, serta laporan penerapannya akan bersifat publik dan termasuk dalam laporan tahunan perusahaan. Rencana Kewaspadaan harus mencakup: 52

1) Pemetaan yang mengidentifikasi, menganalisa, dan tingkatan resiko;

2) Prosedur untuk menilai secara teratur sesuai dengan pemetaan resiko situasi dari anak perusahaan, sub-kontraktor atau dengan siapa saja perusahaan menjalin hubungan bisnis;

3) Tindakan yang tepat untuk mengurangi resiko dan mencegah pelanggaran yang serius;

4) Mekanisme peringatan tentang resiko potensial dan aktual yang dikembangkan secara bersama-sama dengan perwakilan organisasi serikat pekerja dari perusahaan yang bersangkutan;

5) Skema pemantauan untuk menindaklanjuti langkah-langkah yang diterapkan dan efektifitasnya.

Undang-undang ini juga menyebutkan bahwa masyarakat dapat menuntut pertanggungjawaban perusahaan dengan meminta pada otoritas pengadilan untuk memerintahkan kepada perusahaan untuk menentukan, menerbitkan, dan menerapkan Rencana Kewaspadaan bagi perusahaan yang belum membuatnya,

50 "French Duty of Care: Despite Business Preassure, Important Step Made Towads Final Adoption," sumber: http:// corporatejustice.org/news/123-french-duty-of-care-law-despite-business-pressure-an-importantstep-towards-final-adoption, diakses: 3 November 2018

51 Terdapat dua kategori perusahaan yang wajib tunduk terhadap undang-undang ini yaitu: pertama, adalah perusahaan yang pada dua tahun anggaran secara berturut-turut memperkerjakan setidaknya 5000 karyawan di kantor pusat perusahaan dan anak perusahaan secara langsung maupun tidak langsung di wilayah Perancis. Kedua, yaitu perusahaan yang memperkerjakan setidaknya 10.000 karyawan di perusahaan dan anak perusahaan langsung maupun tidak langsung, yang berkantor pusat di Perancis atau di luar negeri. Berdasarkan data yang ada, diperkirakan ada 100-150 perusahaan besar yang memenuhi persyaratan di atas. "French Corporate Duty of Vigilance Law FAQ" sumber: https://www.businesshumanrights.org/sites/default/files/documents/French $\% 20$ Corporate\%20Duty\%20of\%20Vigilance\%20Law\%20FAQ.pdf, diakses 3 Mei 2018

52 "French Corporate Duty of Vigilance Law FAQ", Op. Cit 
dan tindakan ini dapat dikenai denda maksimal 10.000.000 Euro. Di samping itu, masyarakat juga dapat melakukan gugatan perdata dan meminta kompensasi apabila kegiatan perusahaan telah menimbulkan kerusakan. Selain kompensasi, hakim juga dapat mengenakan denda hingga 30.00000.000 Euro.53

Kehadiran UU ini adalah bentuk kemajuan terkait masalah penghormatan perusahaan terhadap hak asasi manusia. Lahirnya UU ini merupakan bentuk kegelisahan terhadap maraknya kerusakan lingkungan dan pelanggaran HAM yang terjadi akibat kegiatan perusahaan di seluruh dunia serta merupakan "tamparan" bagi perusahaan agar jujur dan bertanggung jawab terhadap segala bentuk kegiatan usahanya. ${ }^{44}$

\section{Penutup}

Guiding Principles On Business And Human Rights terdiri dalam 3 kerangka pikir, yaitu; kewajiban negara untuk melindungi hak asasi manusia (state duty to protect), kewajiban perusahaan untuk menghormati hak asasi manusia (corporate responsibility to respect), dan akses pemulihan (remedy). Dalam prinsip kewajiban perusahaan untuk menghormati hak asasi manusia (respect) terdapat suatu alat pertanggungjawaban perusahaan yang disebut dengan uji tuntas hak asasi manusia (human rights due diligence) yang berfungsi sebagai alat untuk mengidentifikasi, mencegah, mitigasi, dan mempertanggungjawabkan dampak pelanggaran hak asasi manusia yang timbul. Di dalam uji tuntas hak asasi manusia ini terdapat apa yang disebut dengan human rights impact assessment sebagai alat untuk mengukur resiko pelanggaran hak asasi manusia dengan mengidentifikasi dan menilai setiap dampak rill dan potensial yang dapat merugikan, dimana perusahaan mungkin terlibat baik melalui aktivitas mereka sendiri ataupun hasil dari hubungan bisnis (supply-chain). Untuk itu negara harus dapat mengakomodir prinsip-prinsip ini dan diatur dalam aturan perundang-undangan sebagaimana yang dilakukan oleh Perancis agar dapat terciptanya CSR yang efektif, tepat sasaran dan bermanfaat bagi negara, perusahaan, dan masyarakat.

53 Ibid

${ }^{54}$ Cossart, Chaplier, dan Beau de Lomenie, "The French Law on Duty of Care: A Historic Step Towards Making Globalization Work for All," Business and Human Rights Journal, Volume 2, Issue 2 Juli 2017, hlm. 317-323 


\section{Daftar Pustaka}

\section{Buku}

Asshiddiqie, Jimly, Hukum Tata Negara dan Pilar-Pilar Demokrasi, Konstitusi Press, Jakarta, 2005.

Global Compact Network Netherlands, Bagaimana Menjalankan Bisnis dengan Menghormati Hak Asasi Manusia, Elsam, Jakarta, 2014.

Kuin, Pieter, Perusahaan Trans Nasional, Yayasan Obor Indonesia, Jakarta, 1987.

Purnomo, Joko, Globalisasi dan Politik Pembangunan Internasional, UB Press, Malang, 2017.

Smith, Rhona K.M. et. al, Hukum Hak Asasi Manusia, Cetakan Pertama, Pusat Studi Hak Asasi Manusia Universitas Islam Indonesia, Yogyakarta, 2008.

Tim Penyusun, Buku Saku: Prinsip-Prinsip Panduan untuk Bisnis dan Hak Asasi Manusia : Kerangka Perserikatan Bangsa-Bangsa Perlindungan, Penghormatan, dan Pemulihan, Konsil LSM Indonesia dan ICCO, Jakarta, 2018.

Thontowi, Jawahir, Hukum dan Hubungan Internasional, UII Press, Yogyakarta, 2016.

Wahyudi, Isa dan Busyra Azheri. Corporate Social Responsibility: Prinsip, Pengaturan dan Implementasi. Malang: Setara Press, 2007.

\section{Jurnal}

Beitz, Berthold, "Interview with John Ruggie," International Review of the Red Cross, Volume 94 Number 887 Autumn 2012.

Cossart, Chaplier, dan Beau de Lomenie, "The French Law on Duty of Care: A Historic Step Towards Making Globalization Work for All," Business and Human Rights Journal, Volume 2, Issue 2 Juli 2017.

Gatto, Alexandra J. C. “The European Union and Corporate Social Responsibility: Can the EU Contribute to the Accountability of Multinational Enterprises for Human Rights?", Working Paper No. 32, Institute for International Law, K. U. Leuven Faculty of Law, September 2002.

Mulyana, Asep, "Mengintegrasikan HAM ke Dalam Kebijakan dan Praktik Perusahaan," Jurnal HAM, Vol 8 Tahun 2012.

, "Paper Bisnis dan HAM: Menurunkan Prinsip Menjadi Praktik", Pusat Dokumentasi Elsam, Jakarta, 2016. Lihat www.elsam.or.id

O’brien, Methven, C., Mehra, A., Blackwell, S., \& Poulsen-Hansen, C., “National Action Plans: Current Status and Future Prospects for a New Business and Human Rights Governance Tool", Business and Human Rights Journal, 1(1), (2016).

Sefriani, "Tanggung Jawab Perusahaan Transnasional terhadap Pelanggaran HAM dalam Perspektif Hukum Internasional", Jurnal UNISIA, Vol. 30, (2007). 
dan Sri Wartini. “Corporate Social Responsibility dan Tanggung Jawab Negara Terhadap Hak Ekonomi, Sosial, dan Budaya di Indonesia", Jurnal Yustisia, Edisi 92, (2015).

\section{Laporan}

International Corporate Accountability Roundtable (ICAR), "National Action Plans on Business and Human Rights: A Toolkit for the Development, Implementation, and Review of State Commitments to Business and Human Rights Frameworks," Juni 2014.

Komisi Nasional Hak Asasi Manusia, "Laporan Data Pengaduan Tahun 2015 Sub Bagian Penerimaan dan Pemilahan Pengaduan", Komnas HAM, Jakarta, 2016.

, “Tindakan Aktif Bagian Dukungan Pelayanan Pengaduan KOMNAS HAM", Laporan Tahunan 2016, Bagian Dukungan Pelayanan Pengaduan Biro Dukungan Penegakan HAM, KOMNAS HAM, Jakarta, 2017.

Ruggie, John, "Report of the Special Representative of the Secretary-General on The Issue Of Human Rights And Transnational Corporations And Other Business Enterprises," UN Document A/HRC/17/31, 2011.

\section{Peraturan Perundang-Undangan dan Instrumen Hukum Internasional}

Guiding Principles On Business And Human Rights, 2011, United Nations Human Rights Council.

Committee on Economic, Social, and Cultural Rights (CESC) General Comments No. 12 The Right to Adequate Food (Art. 11).

Undang-Undang No. 40 Tahun 2007 tentang Perseroan Terbatas; Tambahan Lembaran Negara Republik Indonesia Nomor 4756.

Undang-Undang No. 25 Tahun 2007 tentang Penanaman Modal; Tambahan Lembaran Negara Republik Indonesia Nomor 4724.

Peraturan Pemerintah No. 47 Tahun 2012 tentang Tanggung Jawab Sosial dan Lingkungan Perseroan Terbatas; Tambahan Lembaran Negara Republik Indonesia Nomor 5305.

\section{Internet}

Bauer, Joanne Where Do National Action Plans on Business \& Human Rights Belong in the Corporate Sustainability Movement?, sumber: http://www.csrwire.com/blog/posts/1262- where-do-national-actionplans-on-business-human-rights-belong-in-the-corporate-sustainabilitymovement diakses 4 November 2018

Hussein, Zeid R, "Ethical Pursuit of Porsperity," sumber: https:/ / www.lawgazette.co.uk/analysis/comment-and-opinion/ethicalpursuit-of prosperity/5047796.fullarticle diakses 3 November 2018

Special Representative of the United Nations, Applications of the U.N. "Protect, Respect and Remedy" Framework, Secretary-General for business \& 
human rights, Juni 2011, sumber:https://www.businesshumanrights.org / sites/default/files/media/documents/applications-of-framework-jun2011.pdf

"5 Years of UNGPs: 5 Business and Human Rights Issues to Focus On" sumber: http:/ / corporatejustice.org/news/135-5-years-of-ungps-5-businesshuman-rights-issues-to-focus-on diakses: 3 November 2018

European Comission, “A renewed EU strategy 2011-14 for Corporate Social Responsibility,"

2011,sumber:https:/ / eurlex.europa.eu/legalcontent/EN/TXT/PDF/?uri

$=$ CELEX:52011DC0681 \&from $=$ EN, diakses 5 November 2018

"French Duty of Care: Despite Business Preassure, Important Step Made Towads Final Adoption," sumber:http://corporatejustice.org/news/123-frenchduty-of-care-law-despite-business- pressure-an-important-step-towardsfinal-adoption, diakses: 3 November 2018

"French Corporate Duty of Vigilance Law FAQ" sumber: https://www.businesshumanrights.org/sites/default/files/documents / French \%20Corporate \%20Duty\%20of\%20Vigilance\%20Law\%20FAQ.pdf , diakses 3 ONovember 2018

"United Nation Code of Conduct on Transnational Corporation," sumber: http:/ /investmentpolicyhub.unctad.org/Download/TreatyFile/2891 diakses: 7 Juli 2017

https:/ / nasional.kompas.com/read/2015/09/16/00320091/Sebanyak.127.Orang. dan.10.Perusahaan.Jadi.Tersangka.Kebakaran.Hutan diakses pada 20 Agustus 2016

https://www.merdeka.com/peristiwa/walhi-sebut-pembunuhan-petani-di-lumajang-karenaperusahaan-bermain.html diakses 20 Agustus 2016 https://m.kontan.co.id/ news_analisis/kongkalikong-penguasa-dan-pengusaha, diakses 5 Juli 2018 